\title{
Porphyromonas canoris sp. nov., an Asaccharolytic, Black- Pigmented Species from the Gingival Sulcus of Dogs
}

\author{
DARIA N. LOVE, ${ }^{1 *}$ J. KARJALAINEN, ${ }^{2}$ A. KANERVO, ${ }^{2}$ B. FORSBLOM, ${ }^{2}$ E. SARKIALA, ${ }^{3}$ G. D. BAILEY, ${ }^{1}$ \\ D. I. WIGNEY, ${ }^{1}$ AND H. JOUSIMIES-SOMER ${ }^{2}$ \\ Department of Veterinary Pathology, University of Sydney, Sydney, New South Wales 2006, Australia, ${ }^{1}$ \\ and Anaerobe Reference Laboratory, National Public Health Institute, 00300 Helsinki, ${ }^{2}$ \\ and College of Veterinary Medicine, 00530 Helsinki, ${ }^{3}$ Finland
}

\begin{abstract}
A new species, Porphyromonas canoris, is proposed for black-pigmented asaccharolytic strains isolated from subgingival plaque samples from dogs with naturally occurring periodontal disease. This bacterium is an obligately anaerobic, nonmotile, non-spore-forming, gram-negative, rod-shaped organism. On laked rabbit blood or sheep blood agar plates, colonies are light brown to greenish brown after 2 to 4 days of incubation and dark brown after 14 days of incubation. Colonies on egg yolk agar and on nonhemolyzed sheep blood agar are orange. The cells do not grow in the presence of $20 \%$ bile and have a guanine-plus-cytosine content of 49 to $51 \mathrm{~mol} \%$. The type strain is VPB 4878 (= NCTC 12835). The average levels of DNA-DNA hybridization between $P$. canoris strains and other members of the genus Porphyromonas are as follows: Porphyromonas gingivalis ATCC $33277^{\mathrm{T}}(\mathrm{T}=$ type strain), 6.5\%; Porphyromonas gingivalis cat strain VPB 3492, 5\%; Porphyromonas endodontalis ATCC 35406 ${ }^{\mathrm{T}}$, 1\%; Porphyromonas salivosa $\mathrm{NCTC}_{11362}^{\mathrm{T}}$, 5\%; and Porphyromonas circumdentaria NCTC $12469^{\mathrm{T}}$, 6\%. The level of hybridization between $P$. canoris NCTC $12835^{\mathrm{T}}$ DNA and Porphyromonas asaccharolytica ATCC $25260^{\mathrm{T}}$ DNA is $3 \%$. $P$. canoris cells produce major amounts of acetic, propionic, isovaleric, and succinic acids and minor amounts of isobutyric and butyric acids as end products of metabolism in cooked meat medium. The major cellular fatty acid is 13-methyltetradecanoic acid (iso- $\mathrm{C}_{15: 0}$ ). Glutamate and malate dehydrogenases are present, as are glucose-6-phosphate dehydrogenase activity $\left(65.7 \mathrm{nmol} \mathrm{mg} \mathrm{of} \mathrm{protein}{ }^{-1} \mathrm{~min}^{-1}\right)$ and 6-phosphogluconate dehydrogenase activity $(63.0 \mathrm{nmol} \mathrm{mg}$ of protein $^{-1} \min ^{-1}$ ). $P$. canoris cells do not agglutinate sheep erythrocytes but exhibit brick red fluorescence at $265 \mathrm{~nm}$ and produce catalase.
\end{abstract}

During our investigation of the subgingival flora of 16 family-owned dogs with naturally occurring periodontitis, strictly anaerobic, nonsporing, gram-negative, asaccharolytic, rod-shaped organisms were found frequently $(10,19,20)$. The results of morphological, biochemical, and API ZYM enzyme analyses placed several groups of these organisms in the genus Porphyromonas and DNA-DNA hybridization tests performed by using dot blot assays (12) showed that some of these organisms exhibited homology with either Porphyromonas gingivalis or Porphyromonas salivosa (unpublished data). However, the members of one group, which included 12 of the 259 phenotypically characterized isolates, did not hybridize in the DNA-DNA dot blot assay with any of the currently recognized species in the genus Porphyromonas. However, these strains had a range of characteristics which suggested that they could legitimately belong to the genus Porphyromonas. In this paper, we describe the results of DNA homology studies, a cellular fatty acid analysis, and an allozyme electrophoresis analysis and propose a new species, Porphyromonas canoris.

\section{MATERIALS AND METHODS}

Bacterial strains. A total of 5 of the 12 strains described previously (10) as members of group C2 were examined in more detail in this study. These were strains AHN $4393^{\mathrm{T}}$ (= VPB $\left.4878^{\mathrm{T}}\right)(\mathrm{T}=$ type strain) $(\mathrm{AHN}$, Anaerobe Reference Laboratory, Helsinki Collection; (VPB, Veterinary Pathology and Bacteriology Collection), AHN 4425 (= VPB 4879), AHN

\footnotetext{
* Corresponding author. Mailing address: Department of Veterinary Pathology, Sydney University, New South Wales 2006, Australia. Phone: 61-2-692-2454. Fax: 61-2-552-6526. Electronic mail address: suvp00@angis.su.oz.au.
}

4489 (= VPB 4880), AHN 4446 (= VPB 4881), and AHN 4812 (= VPB 4882); these strains originated from four gingival sulcal sites of three dogs. Strains VPB 4880 and VPB 4882 were isolated from the same site of a dog during different visits 3 months apart. Strains VPB 4879 and VPB 4881 were isolated from two different sites on another dog during the same visit. Strain VPB $4878^{\mathrm{T}}$ was isolated from a third dog. In addition, DNAs were isolated for hybridization studies from feline strains $P$. salivosa NCTC $11632^{\mathrm{T}}\left(=\right.$ VPB $157^{\mathrm{T}}$ ) and VPB 3313, Porphyromonas circumdentaria NCTC $12469^{\mathrm{T}}\left(=\mathrm{VPB} 3329^{\mathrm{T}}\right)$, VPB 3325, and VPB 3497, and $P$. gingivalis VPB 3492, VPB 3318, and VPB 3498 and human strains Porphyromonas endodontalis ATCC $35406^{\mathrm{T}}$, P. gingivalis ATCC $33277^{\mathrm{T}}$, and Porphyromonas asaccharolytica ATCC $25260^{\mathrm{T}}$.

Growth conditions and biochemical methods. The general methods used for growth and biochemical characterization have been described previously $(3,13-15)$. Cells for cellular fatty acid and allozyme assays were grown anaerobically for 2 days on 5\% sheep blood agar plates (Oxoid blood agar base no. 2; Oxoid, Ltd., Basingstoke, England) supplemented with additional hemin-menadione, formate-fumarate (7), and proteose peptone $(1.5 \%$, wt/vol; Difco Laboratories, Detroit, Mich.) in the presence of a streak of Staphylococcus epidermidis (to enhance the growth rate and pigmentation of the colonies).

DNA hybridization assays. The cells used for DNA isolation were grown as described above and harvested in $0.15 \mathrm{M}$ NaCl-0.01 M EDTA ( $\mathrm{pH} 8.0$ ). The cells were lysed by adding sodium dodecyl sulfate to a final concentration of $1 \%(\mathrm{wt} / \mathrm{vol})$. DNAs from the feline strains were isolated by a hydroxyapatite procedure (13), while DNAs from the human type strains and the canine periodontal organisms were isolated essentially by the method of Marmur and Doty (16). 
TABLE 1. Levels of DNA-DNA hybridization for Porphyromonas type strains, feline strains, and P. canoris sp. nov. strains isolated from canine periodontal pockets

\begin{tabular}{|c|c|c|c|c|c|c|c|c|}
\hline \multicolumn{2}{|c|}{ Source of unlabeled DNA } & \multirow[b]{2}{*}{$\begin{array}{c}\mathrm{G}+\mathrm{C} \text { content } \\
(\mathrm{mol} \%)\end{array}$} & \multicolumn{6}{|c|}{$\%$ Hybridization with labeled DNA from ${ }^{a}$ : } \\
\hline Species or group & Strain & & $\begin{array}{c}\text { Strain } \\
\text { VPB } 3492\end{array}$ & $\begin{array}{l}\text { P. circumdentaria } \\
\text { NCTC } 14329^{\mathrm{T}}\end{array}$ & $\begin{array}{c}\text { P. salivosa } \\
\text { NCTC } 11632^{\mathrm{T}}\end{array}$ & $\begin{array}{l}\text { P. canoris } \\
\text { NCTC } \\
12835^{\mathrm{T}}\end{array}$ & $\begin{array}{l}\text { P. endodontalis } \\
\text { ATCC } 35406^{\mathrm{T}}\end{array}$ & $\begin{array}{l}\text { P. gingivalis } \\
\text { ATCC } \\
33277^{\mathrm{T}}\end{array}$ \\
\hline \multirow[t]{3}{*}{$P$. gingivalis cat strains } & VPB 3492 & $50^{b}$ & 100 & $<1$ & 16 & 7 & 4 & 85 \\
\hline & VPB 3318 & 51 & 91 & 6 & 21 & 5 & 6 & 73 \\
\hline & VPB 3498 & 51 & 84 & 5 & 15 & 4 & 3 & 84 \\
\hline$P$. gingivalis & ATCC $33277^{\mathrm{T}}$ & 49 & 95 & 7 & 8 & 4 & 5 & 100 \\
\hline \multirow[t]{3}{*}{$P$. circumdentaria } & NCTC $12469^{\mathrm{T}}$ & 42 & 15 & 100 & 17 & 4 & 5 & 15 \\
\hline & VPB 3325 & 40 & 3 & 92 & 4 & 4 & 3 & $<1$ \\
\hline & VPB 3497 & 40 & 15 & 93 & 5 & 2 & 3 & 19 \\
\hline \multirow[t]{2}{*}{ P. salivosa } & NCTC $11632^{\mathrm{T}}$ & 42 & 18 & 12 & 100 & 4 & 2 & 19 \\
\hline & VPB 3313 & 42 & 19 & 13 & 100 & 4 & 4 & 24 \\
\hline \multirow{4}{*}{ P. canoris sp. nov. } & NCTC $12835^{\mathrm{T}}$ & $50^{c}$ & 7 & 8 & 7 & 100 & $<1$ & 10 \\
\hline & VPB 4879 & $49^{\circ}$ & 7 & 6 & 5 & 91 & 2 & 5 \\
\hline & VPB 4880 & $49^{c}$ & 3 & 5 & 1 & 85 & $<1$ & 5 \\
\hline & VPB 4882 & $51^{c}$ & 3 & 5 & 7 & 84 & $<1$ & 6 \\
\hline P. endodontalis & ATCC $35406^{\mathrm{T}}$ & $\mathrm{ND}^{d}$ & 6 & 9 & 4 & 2 & 100 & 6 \\
\hline P. asaccharolytica & ATCC $25260^{\mathrm{T}}$ & 48 & 2 & 4 & $<1$ & 3 & ND & 9 \\
\hline
\end{tabular}

${ }^{a}$ The reference preparation was normalized to a value of $100 \%$.

${ }^{b}$ DNA was extracted by the hydroxyapatite procedure; the thermal melting point was determined with a Gilford spectrophotometer and a thermoprogrammer.

${ }^{c}$ DNA was extracted by the method of Marmur and Doty (16).

${ }^{d} \mathrm{ND}$, not determined.

G $+\mathbf{C}$ content of DNA. Thermal melting points were used to determine the guanine-plus-cytosine $(\mathrm{G}+\mathrm{C})$ contents of the DNA preparations as described previously (13). Two preparations were made for each organism, and each preparation was used for two separate determinations.

Preparation of labeled nucleic acids. Fragmented, denatured DNA was labeled with ${ }^{125}$ I by using a variation of the thallium chloride method $(21,28)$.

DNA homology methods. Fragmented, denatured DNAs were prepared by three passages through a French pressure cell at $16,000 \mathrm{lb} / \mathrm{in}^{2}$, followed by heating in a boiling water bath for $5 \mathrm{~min}$; the concentration of each preparation was adjusted to $0.4 \mathrm{mg} / \mathrm{ml}$. DNA homology values were determined by using an S1 nuclease procedure as described previously (9). Each reassociation mixture contained $10 \mu \mathrm{l}$ of denatured unlabeled DNA ( 0.01 to $0.03 \mu \mathrm{g}$ ), $50 \mu \mathrm{l}$ of denatured unlabeled DNA (20 $\mu \mathrm{g}), 25 \mu \mathrm{l}$ of $5.28 \mathrm{M} \mathrm{NaCl}-2 \mathrm{mM} \mathrm{N}$-2-hydroxyethylpiperazine$N^{\prime}$-2-ethanesulfonic acid ( $\mathrm{pH} 7.0$ ), and $25 \mu \mathrm{l}$ of deionized formamide. The reassociation vials were incubated for $20 \mathrm{~h}$ at $58^{\circ} \mathrm{C}$. To measure background reassociation values and the amounts of nuclease S1-resistant material in the labeled preparations, the denatured unlabeled DNA was replaced with 50 $\mu \mathrm{l}(20 \mu \mathrm{g})$ of sheared native salmon sperm DNA.

Allozyme electrophoresis. Cells grown for 2 days were harvested from plates with a bent glass rod, suspended in sterile water, and stored at $-140^{\circ} \mathrm{C}$ until they were used. Electrophoresis on Cellogel (Chemetron, Milan, Italy) was performed with supernatant fluids from sonicated cell preparations (Wellcome tube 5 density) by using the method of Richardson et al. (18) to determine the presence of characteristic metabolic pathway enzymes. End points of reactions were determined no later than 15 min after addition of substrate.

Preparation and analysis of fatty acids of whole bacterial cells. Cells were harvested from plates after 2 days with a glass rod (1) and were treated immediately essentially as described by Ghanem et al. (6). A model HP 5890 series II gas chromatograph and a model HP 7673 injector (HewlettPackard) were used for detection. The organic phase was chromatographed by using a fused silica capillary column (type
19091J-102-HP). The column running conditions used have been described previously (6). For fatty acid identification a bacterial acid methyl ester CP mixture (catalog no. 4-7080; Supelco, Bellefonte, $\mathrm{Pa}$.) was chromatographed at the beginning of each run and after each four samples. The total area of each compound and the area percentage of each peak were determined by using a computer program. Equivalent chain lengths were calculated as described in the MIS system instructions (Microbial ID, Inc., Newark, Del.).

Spectrophotometric determination of dehydrogenase activity. Portions of the preparations used for allozyme electrophoresis of strains VPB $4878^{\mathrm{T}}$, VPB 4879 , and VPB 4882 were assayed by using a standard method for glucose-6-phosphate dehydrogenase incorporating maleimide (5). The 6-phosphogluconate dehydrogenase assay was performed like the glucose-6-phosphate dehydrogenase assay except that maleimide was omitted from the assay mixture and 6-phosphogluconate was the substrate. For these assays Bacteroides fragilis ATCC $25285^{\mathrm{T}}$ was used as a species with known dehydrogenase activity $(25,27)$. The activities reported below are the averages of the values obtained in three separate assays per preparation. The Bio-Rad protein assay (Bio-Rad, Richmond, Calif.) was used as recommended by the manufacturer to determine the protein concentration in each preparation.

\section{RESULTS AND DISCUSSION}

Table 1 shows the results of a DNA hybridization assay performed with 4 of the 12 group C2 strains (10) used in this study; in this assay these strains were compared with a representative of each of the previously described species of the genus Porphyromonas. The data in Table 1 show that members of group C2 are distinct from the previously described species of the genus Porphyromonas. The results of the cellular fatty acid analyses of the group C2 strains are compared with the results obtained for previously described members of the genus Porphyromonas in Table 2. The presence of 13-methyltetradecanoic acid (iso- $\mathrm{C}_{15: 0}$ ) as the major acid in these strains is consistent with membership in the genus Porphyromonas. It is 
TABLE 2. Distribution of cellular fatty acids in Porphyromonas strains as determined by gas-liquid chromatography after extraction of methylated whole cells

\begin{tabular}{|c|c|c|c|c|c|c|c|c|c|c|c|c|c|c|c|}
\hline \multirow[b]{2}{*}{ Strain } & \multicolumn{15}{|c|}{ Relative $\%$ of $^{u}:$} \\
\hline & $\mathrm{C}_{14: 0}$ & $\begin{array}{l}\text { iso- } \\
\mathrm{C}_{15: 0}\end{array}$ & $\begin{array}{c}\text { anteiso- } \\
\mathrm{C}_{15: 0}\end{array}$ & $\mathrm{C}_{16: 0}$ & $\begin{array}{l}\text { iso- } \\
\mathrm{C}_{17: 0}\end{array}$ & $\mathrm{C}_{18: 0}$ & $\begin{array}{l}\text { ECL } \\
12.6\end{array}$ & $\begin{array}{l}\text { ECL } \\
12.9\end{array}$ & $\begin{array}{l}\text { ECL } \\
13.6\end{array}$ & $\begin{array}{l}\text { ECL } \\
16.1\end{array}$ & $\begin{array}{l}\mathrm{ECL} \\
16.6\end{array}$ & $\begin{array}{l}\text { ECL } \\
17.5\end{array}$ & $\begin{array}{l}\text { ECL } \\
17.7 \\
\end{array}$ & $\begin{array}{l}\text { ECL } \\
17.8\end{array}$ & $\begin{array}{l}\text { ECL } \\
18.15 \\
\end{array}$ \\
\hline P. canoris NCTC $12835^{\mathrm{T}}$ & 0.4 & 37.2 & 2.9 & 3.5 & 4.7 & 1.6 & 0.4 & 0.6 & 8.0 & 5.1 & 0.9 & 1.8 & 2.7 & 3.5 & 12.8 \\
\hline$P$. canoris VPB 4879 & 0.5 & 38.8 & 3.0 & 3.6 & 3.6 & 1.6 & 0.3 & 0.8 & 9.3 & 5.1 & 1.0 & 1.8 & 2.5 & 3.4 & 20.6 \\
\hline P. canoris VPB 4880 & 0.6 & 56.7 & 1.4 & 2.8 & 1.3 & 1.0 & 0.3 & 0.5 & 15.1 & 1.8 & 1.6 & 0.5 & 0.9 & 1.4 & 11.2 \\
\hline P. canoris VPB 4881 & 0.7 & 38.6 & 3.1 & 3.5 & 3.4 & 1.6 & 0.3 & 0 & 5.3 & 5.9 & 1.1 & 2.2 & 2.5 & 3.5 & 26.1 \\
\hline P. canoris VPB 4882 & 0.5 & 52.5 & 4.1 & 2.1 & 2.1 & 1.0 & 0.9 & 0 & 3.1 & 6.0 & 0.6 & 1.2 & 1.6 & 2.2 & 20.2 \\
\hline P. gingivalis ATCC $33277^{\mathrm{T}}$ & 2.5 & 29.3 & 9.2 & 9.7 & 2.1 & 1.2 & 2.0 & 1.7 & 11.2 & 2.1 & 0 & 3.8 & 0 & 0 & 12.8 \\
\hline P. salivosa NCTC $11632^{\mathrm{T}}$ & 2.3 & 41.9 & 9.8 & 8.0 & 1.4 & 1.5 & 3.9 & 2.6 & 17.2 & 0 & 1.5 & 1.3 & 1.7 & 3.3 & 2.9 \\
\hline $\begin{array}{l}\text { P. circumdentaria NCTC } \\
12469^{\mathrm{T}}\end{array}$ & 1.4 & 55.7 & 1.8 & 10.9 & 6.7 & 1.5 & 0.4 & 0 & 3.2 & 2.5 & 0 & 0.7 & 1.4 & 2.3 & 9.8 \\
\hline $\begin{array}{l}\text { P. asaccharolytica NCTC } \\
25260^{\mathrm{T}}\end{array}$ & 1.4 & 63.4 & 1.6 & 4.3 & 2.6 & 0.8 & 1.9 & 0.5 & 11.3 & 1.3 & 1.7 & 0.2 & 0.4 & 1.3 & 3.3 \\
\hline P. endodontalis ATCC $35406^{\mathrm{T}}$ & 0 & 31.5 & 2.6 & 6.6 & 0.4 & 1.1 & 0.2 & 0.4 & 12.5 & 5.4 & 1.8 & 1.1 & 1.1 & 1.7 & 29.0 \\
\hline
\end{tabular}

${ }^{a}$ The relative amount of each fatty acid is expressed as the area of its peak as a percentage of the total area of the peaks of all of the fatty acids detected. ECL, equivalent chain length. There was no $\mathrm{C}_{15: 0}$ in any strain.

generally accepted that the presence of iso- $\mathrm{C}_{15: 0}$ as the major branched-chain cellular fatty acid is a characteristic of the genus Porphyromonas $(1,2,11,14,17,22-24)$, and this characteristic is considered by Brondz et al. (1) to constitute a true taxonomic marker of the genus Porphyromonas, although iso- $\mathrm{C}_{15: 0}$ also is a major acid in the genera Tissierella and Reikenella (17a). However, allozyme electrophoresis of four metabolic enzymes showed that malate and glutamate dehydrogenases were present as required for members of the genus Porphyromonas (24) but that glucose-6-phosphate dehydrogenase and 6-phosphogluconate dehydrogenase were also present. In order to check that the latter results were true enzymatic reaction results, the spectrophotometric assay described above was carried out. The average glucose-6-phosphate dehydrogenase activity for the three strains examined was $54.8 \mathrm{nmol} \mathrm{mg}$ of protein ${ }^{-1} \mathrm{~min}^{-1}$ (compared with 96.2 nmol mg of protein ${ }^{-1} \min ^{-1}$ for $B$. fragilis), and the average 6-phosphogluconate dehydrogenase activity was $54.4 \mathrm{nmol} \mathrm{mg}$ of protein ${ }^{-1} \mathrm{~min}^{-1}$ (compared with $35.9 \mathrm{nmol} \mathrm{mg}$ of protein $^{-1} \mathrm{~min}^{-1}$ for $B$. fragilis). The latter results are at variance with the results obtained for other members of the genus
Porphyromonas. However, if the key features of the genus Bacteroides (which is the only other genus of anaerobic, gram-negative, nonmotile, nonsporing, rod-shaped bacteria known to have this set of metabolic enzymes) are examined, the group $\mathrm{C} 2$ cluster cannot be considered a member of this genus as it has been defined $(8,25,26)$. Members of the genus Bacteroides are nonpigmented, highly fermentative, rodshaped organisms which produce major amounts of acetic and succinic acids. Characteristically, they have 12-methyltetradecanoic acid (anteiso- $\mathrm{C}_{15: 0}$ ) as their major long-chain cellular fatty acid. In addition, Bacteroides strains contain pentadecanoic acid $\left(\mathrm{C}_{15: 0}\right)$, which is not present in all Porphyromonas strains that have been described. Nor are the characteristics of the group $\mathrm{C} 2$ strains consistent with the characteristics of other nonfermentative gram-negative anaerobes that have been redefined recently (4). For example, members of the genus Tissierella are motile rod-shaped organisms which do not produce pigment, are indole negative, and have a DNA G+C content of $28 \mathrm{~mol} \%$. Table 3 shows biochemical and enzyme reactions which may be helpful in differentiating species within the genus Porphyromonas. While the group $\mathrm{C} 2$ strains do not fit

TABLE 3. Selected characteristics of members of the genus Porphyromonas which may enable differentiation of species: comparison of canine strains of $P$. canoris sp. nov. with feline and human members of the genus

\begin{tabular}{|c|c|c|c|c|c|c|c|c|c|c|c|}
\hline Strain & 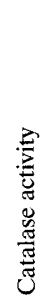 & 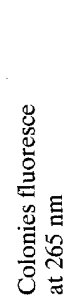 &  & 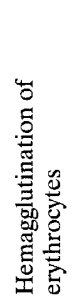 & 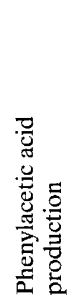 & 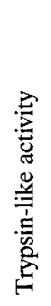 & 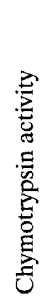 & 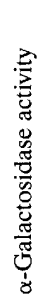 & 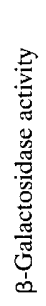 & 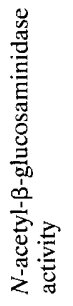 & 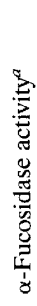 \\
\hline P. asaccharolytica ATCC $25260^{\mathrm{T}}$ & $-{ }^{b}$ & + & - & - & - & - & - & - & - & - & + \\
\hline P. endodontalis ATCC $35406^{\mathrm{T}}$ & - & + & - & - & - & - & - & - & - & - & - \\
\hline$P$. gingivalis ATCC $33277^{\mathrm{T}}$ & - & - & - & + & + & + & - & - & - & + & - \\
\hline P. gingivalis VPB 3492 & + & - & - & + & + & + & - & - & - & + & - \\
\hline$P$. salivosa $\mathrm{NCTC} 11632^{\mathrm{T}}$ & + & $-{ }^{c}$ & + & - & + & + & + & + & - & + & - \\
\hline P. circumdentaria NCTC $124969^{\mathrm{T}}$ & + & + & - & - & + & - & - & - & - & - & - \\
\hline$P$. canoris NCTC $12835^{\mathrm{T}}$ & + & + & $-d$ & - & - & - & + & - & + & + & - \\
\hline
\end{tabular}

${ }^{a}$ Detected by API ZYM tests (3).

${ }^{b}+$, activity; - , no activity.

${ }^{c}$ The type strain does not fluoresce; other strains may fluoresce (13).

${ }^{d}$ A yellowish orange pigment is produced on egg yolk agar. 
clearly into the genus Porphyromonas as currently defined, the available data (for example, comparable $\mathrm{G}+\mathrm{C}$ contents, nonfermentative metabolism, fatty acid composition, dark pigmentation) suggest that this cluster belongs in an emended genus Porphyromonas whose description does not contain a requirement for a lack of glucose- 6 phosphate dehydrogenase and 6-phosphogluconate dehydrogenase activities.

Description of Porphyromonas canoris sp. nov. Porphyromonas canoris (can' or. is. L. n. canis, dog; L. gen. n. oris, of the mouth; N.L. gen. n. canoris, of a dog's mouth). Cells are obligately anaerobic, nonsporing, nonmotile, gram-negative rods or coccoid forms. In cooked meat carbohydrate medium (14) and on sheep blood agar plates, cells are 0.3 to 0.6 by 0.8 to $1.5 \mu \mathrm{m}$ and are arranged singly and in groups; filaments up to $16 \mu \mathrm{m}$ long are seen occasionally. On sheep blood agar plates, surface colonies after $48 \mathrm{~h}$ are $1.5 \mathrm{~mm}$ in diameter, circular, and rough and have orange pigmentation. Colonies exhibit brick red fluorescence $(265 \mathrm{~nm})$ after 3 and 6 days, and after 13 days the fluorescence is light orange. On laked rabbit or sheep blood medium, colonies are light brown to greenish brown after 2 to 4 days and black after 12 days of incubation. Vitamin $\mathrm{K}$ and hemin are required for growth. After incubation for 5 days, the $\mathrm{pH}$ values in media containing carbohydrates (uninoculated $\mathrm{pH}, 6.8$ to 7.4 ) generally range from 6.3 to 6.5. Carbohydrate fermentation is not detected in the presence of adonitol, cellobiose, fructose, glucose, glycogen, inositol, lactose, maltose, mannitol, rhamnose, salicin, starch, sucrose, trehalose, and xylose. Ammonia is produced from cooked meat medium (14).

The short-chain fatty acids produced in cooked meat medium are acetate (average concentration, $36.7 \mu \mathrm{mol} / \mathrm{ml}$ ), propionate (average concentration, $42.5 \mu \mathrm{mol} / \mathrm{ml}$ ), isovalerate (average concentration, $10.1 \mu \mathrm{mol} / \mathrm{ml}$ ), and succinate (average concentration, $15.6 \mu \mathrm{mol} / \mathrm{ml}$ ); in addition, minor amounts of isobutyrate (average concentration, $2.8 \mu \mathrm{mol} / \mathrm{ml}$ ) and butyrate (average concentration, $4.3 \mu \mathrm{mol} / \mathrm{ml}$ ) are produced. No phenylacetic acid is detected. Lactate is converted to propionate, but pyruvate is not utilized, and threonine is not converted to propionate. Strains are catalase positive and indole positive, liquefy gelatin, and are alkaline and acid phosphatase positive, but do not exhibit trypsin-like activity or produce lipase or lecithinase. They produce chymotrypsin, $N$-acetyl- $\beta$-glucosaminidase, and $\beta$-galactosidase but do not produce $\alpha$-galactosidase or $\alpha$-fucosidase. Cells do not hemagglutinate sheep erythrocytes. Nitrate is not reduced, urea is not split, and esculin is not hydrolyzed. Malate, glutamate, glucose-6-phosphate, and 6-phosphogluconate dehydrogenases are present. The predominant cellular fatty acid is 13 -methyltetradecanoic acid (iso- $\mathrm{C}_{15: 0}$ ); smaller amounts of the acids shown in Table 2 are also present.

Strains are susceptible to penicillin $(2 \mathrm{U} / \mathrm{ml})$, amoxicillin $(2.5$ $\mu \mathrm{g} / \mathrm{ml})$, carbenicillin $(100 \mu \mathrm{g} / \mathrm{ml})$, and erythromycin $(3 \mu \mathrm{g} / \mathrm{ml})$.

All strains were isolated from subgingival pockets of dogs with naturally occurring periodontitis. The $\mathrm{G}+\mathrm{C}$ content of the DNA is 49 to 51 mol\% as determined by the thermal denaturation method (16). The average level of intraspecies DNADNA hybridization is $90 \%$. The average levels of DNA-DNA hybridization between strain VPB $4878^{\mathrm{T}}$ (= NCTC $12835^{\mathrm{T}}$ ) and other members of the genus Porphyromonas are as follows: $P$. gingivalis ATCC $33277^{\mathrm{T}}, 4 \% ; P$. salivosa, $4 \%$; cat strains of $P$. gingivalis, $5 \% ; P$. endodontalis ATCC $35406^{\mathrm{T}}, 2 \% ; P$. circumdentaria, $3 \%$; and $P$. asaccharolytica ATCC $25260^{\mathbf{T}}, 3 \%$.

The type strain is NCTC 12835 (= VPB 4878).

Characteristics which distinguish $P$. canoris sp. nov. from other members of the genus Porphyromonas are summarized in Table 3.

\section{ACKNOWLEDGMENTS}

This work was supported in part by the Australian Research Council.

Prereduced and other bacteriological media were prepared by $\mathbf{L}$. Patoka and F. Taeker.

\section{REFERENCES}

1. Brondz, I., J. Carlsson, M. Sjostrom, and G. Sundqvist. 1989. Significance of cellular fatty acids and sugars in defining the genus Porphyromonas. Int. J. Syst. Bacteriol. 39:314-318.

2. Brondz, I., and I. OIsen. 1991. Multivariate analyses of cellular fatty acids in Bacteroides, Prevotella, Porphyromonas, Wolinella, and Campylobacter spp. J. Clin. Microbiol. 29:183-189.

3. Collings, S., and D. N. Love. 1992. Further studies on some physical and biochemical characteristics of asaccharolytic pigmented Bacteroides of feline origin. J. Appl. Bacteriol. 72:529-535.

4. Collins, M. D., and H. N. Shah. 1986. Reclassification of Bacteroides praeacutus Tissier (Holdeman and Moore) in the new genus Tissierella, as Tissierella praeacuta comb. nov. Int. J. Syst. Bacteriol. 36:461-463.

5. Deutsch, J. 1983. Glucose-6-phosphate dehydrogenase, p. 190197. In H. V. Bergmeyer (ed.), Methods in enzymatic analysis, vol. 3, 3rd ed. Verlag Chemie, Weinheim, Germany.

6. Ghanem, F. M., A. C. Ridpath, W. E. C. Moore, and L. V. H. Moore. 1991. Identification of Clostridium botulinum, Clostridium argentinense, and related organisms by cellular fatty acid analysis. J. Clin. Microbiol. 29:1114-1124.

7. Holdeman, L. V., E. P. Cato, and W. E. C. Moore (ed.). 1977. Anaerobe laboratory manual, 4th ed. Virginia Polytechnic Institute and State University, Blacksburg.

8. Holdeman, L. V., R. W. Kelley, and W. E. C. Moore. 1984. Genus 1. Bacteroides Castellani \& Chalmers 1919, 959, p. 604-631. In N. R. Krieg, and J. G. Holt (ed.), Bergey's manual of systematic bacteriology, vol. 1. The Williams \& Wilkins Co., Baltimore.

9. Johnson, J. L. 1985. DNA reassociation and RNA hybridization of bacterial nucleic acids. Methods Microbiol. 18:33-74.

10. Karjalainen, J., A. Kanervo, M.-L. Vaisanen, B. Forsblom, E. Sarkiala, and H. Jousimies-Somer. 1993. Porphyromonas-like gram-negative rods in naturally occurring periodontitis in dogs. FEMS Immunol. Med. Microbiol. 6:207-212.

11. Lambe, D. W., K. P. Ferguson, and W. R. Mayberry. 1982. Characterization of Bacteroides gingivalis by direct fluorescent antibody staining and cellular fatty acid profiles. Can. J. Microbiol. 28:367-374.

12. Love, D. N., G. D. Bailey, and D. Bastin. 1992. Chromosomal DNA probes for the identification of asaccharolytic anaerobic pigmented bacterial rods from the oral cavity of cats. Vet. Microbiol. 31:287-295.

13. Love, D. N., J. L. Johnson, R. F. Jones, and A. Calverley. 1987. Bacteroides salivosus sp. nov., an asaccharolytic black-pigmented Bacteroides species from cats. Int. J. Syst. Bacteriol. 37:307-309.

14. Love, D. N., R. F. Jones, and M. Bailey. 1979. Clostridium villosum sp. nov. from subcutaneous abscesses in cats. Int. J. Syst. Bacteriol. 29:241-244.

15. Love, D. N., R. F. Jones, and A. Calverley. 1984. Asaccharolytic black-pigmented Bacteroides strains from soft-tissue infections in cats. Int. J. Syst. Bacteriol. 34:300-303.

16. Marmur, J., and P. Doty. 1962. Determination of base composition of deoxyribonucleic acid from its thermal denaturation temperature. J. Mol. Biol. 5:109-118.

17. Mayberry, W. R., D. W. Lambe, and K. P. Ferguson. 1982. Identification of Bacteroides species by cellular fatty acid profiles. Int. J. Syst. Bacteriol. 32:21-27.

17a.Moore, L. V. H. Personal communication.

18. Richardson, B. J., P. R. Baverstock, and M. Adams. 1986. Allozyme electrophoresis. A handbook for animal systematics and population studies. Academic Press, Sydney, Australia.

19. Sarkiala, E. M., S. Asikainen, A. Kanervo, J. Junttila, and H. R. Jousimies-Somer. The efficacy of tinidazole in naturally occurring periodontitis in dogs: bacteriological and clinical results. Vet. Microbiol., in press.

20. Sarkiala, E. M., S. Asikainen, J. Wolf, A. Kanervo, I. Happonen, and H. Jousimies-Somer. 1993. Clinical, radiological and bacteri- 
ological findings of naturally occurring periodontitis in dogs. $\mathbf{J}$. Small Anim. Pract. 34:265-270.

21. Selin, Y. M., B. Harich, and J. L. Johnson. 1983. Preparation of labeled nucleic acids (nick translation and iodination) for DNA homology and rRNA hybridization experiments. Curr. Microbiol. 8:127-132.

22. Shah, H. N., and M. D. Collins. 1980. Fatty acid and isoprenoid quinone composition in the classification of Bacteroides melaninogenicus and other related taxa. J. Appl. Bacteriol. 48:75-87.

23. Shah, H. N., and M. D. Collins. 1983. A review. Genus Bacteroides. A chemotaxonomical perspective. J. Appl. Bacteriol. 55:403-416.

24. Shah, H. N., and M. D. Collins. 1988. Proposal for reclassification of Bacteroides asaccharolyticus, Bacteroides gingivalis, and Bacte- roides endodontalis in a new genus, Porphyromonas. Int. J. Syst. Bacteriol, 38:128-131.

25. Shah, H. N., and M. D. Collins. 1989. Proposal to restrict the genus Bacteroides (Castellani and Chalmers) to Bacteroides fragilis and closely related species. Int. J. Syst. Bacteriol. 39:85-87.

26. Shah, H. N., and M. D. Collins. 1990. Prevotella, a new genus to include Bacteroides melaninogenicus and related species formerly classified in the genus Bacteroides. Int. J. Syst. Bacteriol. 40:205208.

27. Shah, H. N., and R. A. D. Williams. 1982. Dehydrogenase patterns in the taxonomy of Bacteroides. J. Gen. Microbiol. 128:2955-2965.

28. Tereba, A., and B. J. McCarthy. 1973. Hybridization of ${ }^{125}$ I-labeled ribonucleic acid. Biochemistry 12:4675-4679. 